\title{
Effect of pasture composition on lime and phosphorus responses on a dryland soil
}

\author{
D.C. EDMEADES, D.M. WHEELER, G. RYS' and N. SMITH' \\ MAF Technology, Ruakura Agricultural Centre, Private Bag, Hamilton \\ 'MAF Technology, P.0. Box 760, Hastings
}

\begin{abstract}
A field trial was conducted on a yellow-grey earth in the Hawke's Bay (mean annual rainfall $875 \mathrm{~mm}$ ) over a period of 5 years to measure the effects of lime applications $(0,5,10 \mathrm{t} / \mathrm{ha})$ on soils high (50 kg P/ha applied annually) or low (5 $\mathrm{kg} \mathrm{P} /$ ha applied annually) in phosphorus $(\mathrm{P})$. The average annual pasture production on this dryland soil in the absence of applied lime or $\mathrm{P}$ was $5060 \mathrm{~kg} \mathrm{DM} / \mathrm{ha}$ (range 3861-6024). The botanical composition of the pasture was variable, average annual legume composition ( $\%$ on DM basis) ranging from 3 to $42 \%$. The predominant. legume was subterranean clover (Trifolium subterranean) with white clover (Trifolium repens) making a small contribution in some years. In the first two years after application responses to lime were large $(10-20 \%)$, due entirely to liming stimulating the grass component of the pasture, and consistent with liming enhancing the rate of net mineralisation of soil organic nitrogen $(\mathrm{N})$. In years three and-four-the-dominant treatment effect was to $\mathrm{P}$ applications $(>\mathbf{3 0 \%}$ increase in total pasture production), which stimulated legume growth initially, but subsequently increased grass growth. In the fifth year no significant responses to lime or $\mathrm{P}$ were observed. The seasonal pattern of pasture responses to either lime or $\mathrm{P}$ was related to pasture botanical composition. The size of the annual total $\mathrm{DM}$ pasture responses to $\mathrm{P}$ was positively related to the legume content of the pasture. Conversely the lime responses were negatively related to pasture legume content. These results suggest that pasture botanical composition could be used to improve the ability to predict lime and $\mathrm{P}$ responses based on soil nutrient levels. This may be important where pasture botanical composition is extremely variable over time.
\end{abstract}

Keywords fertiliser, lime, pasture, pasture composition, phosphorus, soil acidity

\section{Introduction}

Pasture production responses to lime and phosphorus $(\mathrm{P})$ inputs are variable over time and space and cannot be attributed solely to differences in soil pH or soil P status (Edmeades et al. 1984a; Saunders et al. 1987). This is a major difficulty when attempting to develop predictive models of lime and $\mathrm{P}$ inputs. Edmeades et al. (1984a) cited four possible explanations to account for variable lime responses at a given $\mathrm{pH}$, one of which was pasture botanical composition. They argued that if different pasture species have different $\mathrm{pH}$ optima or different sensitivities to acidity, then pasture composition will influence the degree of response to liming. Similarly, pasture botanical composition has been used to rationalise different $\mathrm{P}$ inputs required for maximum production on ryegrass-white clover and browntopdominated pastures (Edmeades et al. 1984b).

This paper reports some results from a field trial designed to examine the effects of lime and $\mathrm{P}$ on pasture production. During the trial the botanical composition of the pasture varied- markedly, providing a unique opportunity to examine the impact of these changes on the size of the observed lime and $\mathrm{P}$ responses.

\section{Methods}

A field trial was conducted on a yellow-grey earth (annual rainfall $875 \mathrm{~mm}$ ) on the southern coast of Hawkes Bay at Summerlee Station. The trial was managed under a mowing-clippings return regime with all stock excluded. There were 10 treatments with 4 replicates in a randomised block design. Plot size was $6 \mathrm{~m} \times 1.5 \mathrm{~m}$. The treatments of concern to this paper included 3 rates of lime' $(0,5$ and 10 tha $)$ with high $(50 \mathrm{~kg} / \mathrm{ha} / \mathrm{yr})$ and low $(5 \mathrm{~kg} / \mathrm{ha} / \mathrm{yr})$ levels of applied P. Treatments were initally applied in winter 1979. Basal fertiliser consisting of $\mathrm{K}(90$ $\mathrm{kg} / \mathrm{ha} / \mathrm{yr}$, split application), S (34 kg/ha/yr, split application), Mg (20 kg/ha/yr for 3 years), Mo (150 
Table 1 Total and seasonal pasture dry matter (DM) production and the legume contribution to DM production on a yellow-grey earth in Hawke's Bay.

\begin{tabular}{|c|c|c|c|c|c|c|c|c|c|}
\hline \multirow[t]{2}{*}{ Year } & \multirow[t]{2}{*}{$\begin{array}{l}\text { Total pasture production }{ }^{1} \\
\left(\begin{array}{ll}\mathrm{kg} & \mathrm{DM} / \mathrm{ha})\end{array}\right.\end{array}$} & \multicolumn{2}{|c|}{ Seasonal } & \multicolumn{2}{|c|}{ production" } & \multicolumn{4}{|c|}{$\begin{array}{c}\text { Legume contribution' to } \\
\text { total production }\end{array}$} \\
\hline & & $S$ & $S$ & $\mathrm{~A}$ & $\mathrm{~W}$ & $\mathrm{~S}$ & $S$ & $\mathrm{~A}$ & $\mathrm{~W}$ \\
\hline $1979-80$ & 5528 & 49 & 13 & 31 & 7 & 39 & 2 & 2 & 0 \\
\hline $1980-81$ & 5458 & 41 & 36 & 7 & 11 & 9 & 4 & 9 & 6 \\
\hline 1981- 82 & 4438 & 49 & 11 & 30 & 11 & 42 & 22 & 15 & 33 \\
\hline 1982-83 & 3861 & 78 & 1 & 3 & 18 & 49 & 0 & 3 & 12 \\
\hline $1983-84$ & 6024 & 51 & 15 & 23 & 11 & 27 & 5 & 0 & 5 \\
\hline Mean & 5062 & 54 & 15 & 19 & 12 & 49 & 15 & 21 & 14 \\
\hline
\end{tabular}

1 in the absence of applied lime or phosphorus

$2 \%$ of total production occurring in each season

$3 \%$ of total seasonal production due to legume

$\mathrm{g}$ /ha first year then $30 \mathrm{~g} / \mathrm{ha} / \mathrm{yr})$, and trace $(\mathrm{Cu}, \mathrm{B}, \mathrm{Zn}$ at $3.8,1.7$ and $3.5 \mathrm{~kg} / \mathrm{ha} / \mathrm{yr}$, respectively) were applied.

For the purposes of statistical analysis the following seasons were chosen: spring (September, October, November), summer (December, January, February), autumn (March, April, May) and winter (June, July, August). Harvests occurring on the boundary of seasons were apportioned between seasons according to the number of days. When there were more than 35 days between harvests, production was apportioned to the season coinciding with the last 35 days.

Soil samples were taken yearly and analysed for pH and Olsen P (Ruakura Soil Laboratory). Soil test values of the control plots at the trial commencement were: $\mathrm{pH}$ 5.2; Olsen $\mathrm{P}$ 5; Quick Tests $\mathrm{K}, \mathrm{Mg}$ and $\mathrm{Ca}$ 6,4 and 5 , respectively.

\section{Results}

The average annual pasture production on this dryland soil was $5060 \mathrm{~kg} \mathrm{DM} / \mathrm{ha}$ (range 3861 to 6024) (Table 1), about half of which occurred in the spring. Summer and autumn production contributed $15 \%$ and $19 \%$ of total annual production on average, but this was extremely variable.

The legume component of the pasture was predominantly subterranean clover (Trifolium subterranean) with small quantities (9-14\% of total DM) of white clover (Trifolium repens) being present in years three and five. Except for year two, the legume component contributed $27-49 \%$ of the total spring production (Table 1). The legume contribution in other seasons was extremely variable.

The effects of lime and $\mathrm{P}$ on total production and on the production of the grass and legume components for each year are given in Figure 1. In years 1 and 2 , the dominant treatment effect was that of liming, which at both high and low $\mathrm{P}$ input, significantly $(\mathrm{P}<0.05)$ increased total production. This effect of liming was due entirely to the stimulation of grass growth (Figure 1). Neither lime nor $\mathrm{P}$ had a significant $(\mathrm{P}<0.05)$ effect on the growth of the legume component.
In years three and four, lime applications at high $\mathrm{P}$ input either had no effect, or tended to decrease, total pasture productidn. These same effects occurred for the grass and legume components. At low $\mathrm{P}$ inputs, liming, at least at the highest rate (10 $\mathrm{t} / \mathrm{ha})$, stimulated $(\mathrm{P}<0.05)$ both grass and legume production and hence total pasture production. In contrast to years one and two, $\mathrm{P}$ applications significantly $(\mathrm{P}<0.05)$ increased total, grass and legume production in years three and four.

By year five neither lime nor $\mathrm{P}$ applications significantly $(\mathrm{P}<0.05)$ affected total pasture production or the production of the legume and grass components.

Statistically significant lime x $\mathrm{P}$ interactions occurred only in years three and four for total production, and in year four for grass production.

The major effect of liming was on the grass component of the pasture (Figure 2). Liming had no significant effect on seasonal legume production. Also the effect of liming of the grass component generally decreased over time.

Initially $\mathrm{P}$ had no effect on the growth of either the grass or legume component (Figure 3 ), but from year three onwards the legume component initially, and subsequently the grass component, responded to $\mathrm{P}$ applications.

\section{Discussion}

The pasture production response to liming was due entirely to the stimulation of the grass component. This effect of liming has been observed in other field trials (Cullen \& Grigg 1971; Nyborg \& Hoyt 1978; Edmeades et al. 1986; Edmeades et al. 1989) and is consistent with liming enhancing the rate of net mineralisation of soil organic $\mathrm{N}$. The grass component responds to this increase in $\mathrm{N}$ availability because it is entirely dependent on soil $\mathrm{N}$ for its $\mathrm{N}$ supply, whereas the legume component is not.

This effect of liming can be of sufficient magnitude to account for pasture responses to liming. For example, in a field trial on a yellowbrown loam in Taranaki (Edmeades et al. 1986), liming 'released' the equivalent of $25 \mathrm{~kg} \mathrm{~N} / \mathrm{ha} / \mathrm{yr}$, at 

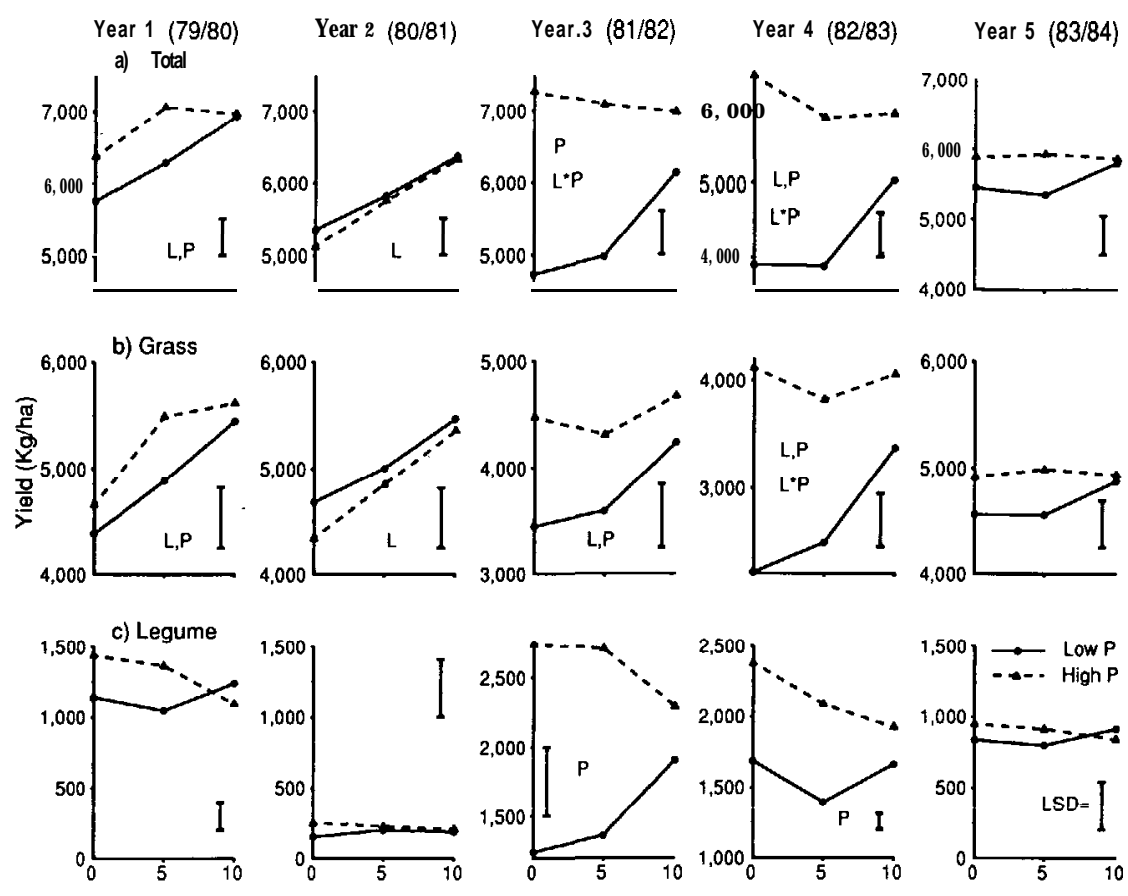

Lime Rate (T/ha)

Figure 1 The effects of liming on annual (a) total (b) grass and (c) legume dry matter production at high (broken line) and low (solid line) phosphorus inputs. (Least significant difference given by the size of the vertical bar and the presence of the letters L, P. L*P indicate the occurrence of statistically significant lime, phosphorus or lime $\mathbf{X}$ phosphorus interactions respectively).

least in the initial 2 years after application. Similar results have been obtained on a pasture on a yellowbrown earth (Edmeades et al. 1989).

This important effect of lime is often ignored as a possible explanation for lime responses. This may be especially-important -in-glasshouse-experiments, were the environmental conditions, together with the fact that the soils are 'disturbed', will enhance this effect (Edmeades et al. 1981). While the effects of lime in this trial contradict the commonly held view that liming benefits the legume component of pastures, it must be noted that molybdenum (Mo) was applied as a basal dressing in this trial. Hence the well documented beneficial effect of lime on soil Mo availability (During 1972), which directly affects legume growth, would not have been observed.

There was a trend for the size of the lime response to decline over time (Figure 2). The most likely reason for this was the gradual but consistent increase in soil $\mathrm{pH}$ of the control plots over time from 5.2 (1980) to 5.7 (1984), given that lime responsiveness is inversely related to soil $\mathrm{pH}$ (Edmeades et al. 1984). However, we cannot discount from these results the possibility that the effect of liming on enhanced $\mathrm{N}$ mineralisation is a one-off effect. Once the new pH-N mineralisation equilibrium is established, the increased pool of available $\mathrm{N}$ in the soil-plant system may gradually decline over time as a result of $\mathrm{N}$ losses. Thus the lime response may also decline. This is consistent
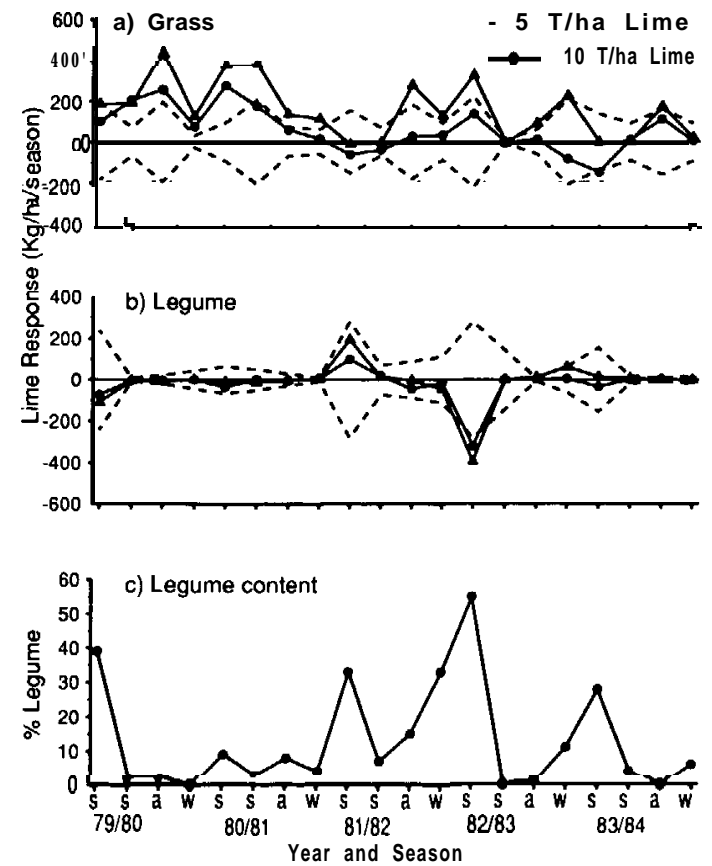

Figure 2 The effects of lime ( 5 or $10 \mathrm{t} / \mathrm{ha}$ ) (meaned over the 2 phosphorus levels) on seasonal (a) grass (b) legume dry matter production in relation to (c) seasonal pasture legume composition ( $\%$ dry matter basis). (Dotted line indicates LSD). 

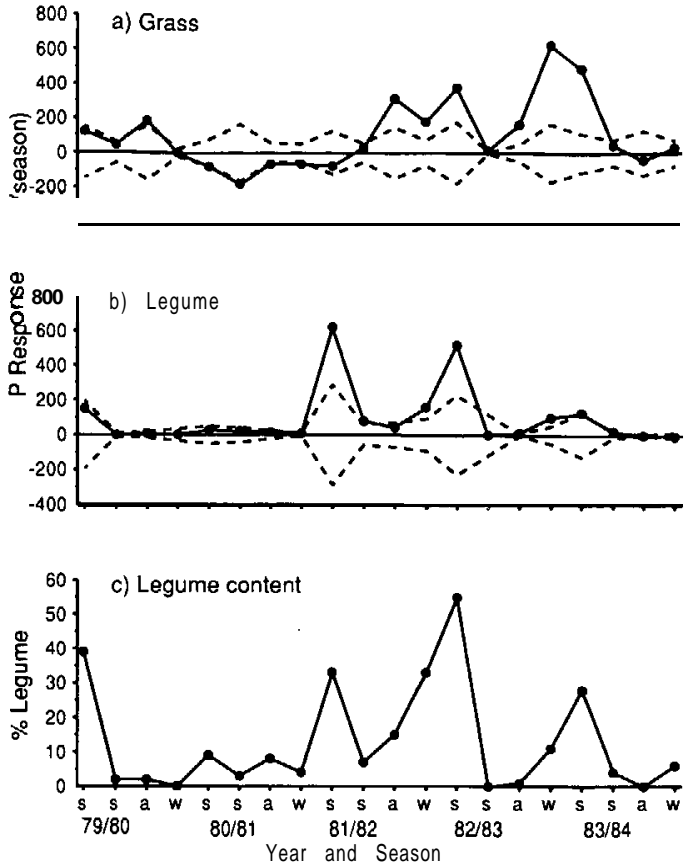

Figure 3 The effects of applied phosphorus (50 kg/ha/yr) (meaned over the 2 lime rates) on seasonal (a) grass (b) legume dry matter production in relation to (c) seasonal pasture legume composition ( $\%$ dry matter basis). (Dotted line indicates LSD).

with results on a cropping soil (Nyborg \& Hoyt 1978), but further long-term research will be required to establish this on pastoral soils.

In years one, two and five the site was not responsive to $\mathrm{P}$ applications $(50 \mathrm{~kg} \mathrm{P} / \mathrm{ha} / \mathrm{yr})$. This was surprising given the low soil $\mathrm{P}$ status of the site (Olsen P, 5). A plausible reason for this lack of $\mathrm{P}$ responsiveness is the extremely poor legume content at this site in these years, assuming that the legume component has a higher requirement for $\mathrm{P}$ than the grasses.

In years three and four, the legume content of the pasture was much higher (presumably due to favourable autumn reseeding conditions for the annual legumes), and production responses to $\mathrm{P}$ applications were significant. This response to $\mathrm{P}$ was observed initially in the legume component and subsequently, and increasingly, in the grasses.

Statistically significant lime x P interactions for total pasture production occurred in two of the five years. These interactions were negative and can be described as P-sparing effects of liming, using the definition of Mansell et al. (1984). However, the fact that such interactions have not occurred consistently in this trial is consistent with other evidence (Manse11 et al. 1986) and suggests that these soils should not be limed in the expectation that $\mathrm{P}$ inputs can be reduced.
The influence of pasture botanical composition on the size of lime and $\mathrm{P}$ responses is shown in Figure 4. There is clearly a trend for the annual $\mathrm{P}$ response to increase with increasing legume content. This makes sense on the assumption that legumes have a higher $\mathrm{P}$ requirement and hence are more $\mathrm{P}$ responsive. In contrast, lime responsiveness of this site is negatively related to the legume content (Figure 4), supporting the earlier contention that the main mechanism by which liming increases production on this soil is through increasing net soil $\mathrm{N}$ mineralisation. These results suggest that pasture composition data may usefully improve the prediction of the size of lime and $P$ responses based soley on soil test levels, and should be considered as an important factor when developing predictive nutrient models. This may be important only for situations such as drought-prone soils where there are large fluctuations in pasture botanical composition over time.

Equally, these results emphasise the need to conduct long-term trials so that the biological variations in botanical composition, and their impact on the size of lime and $\mathrm{P}$ responses, are integrated into any general recommendation which may be derived from that trial.

Although the variable pattern of pasture responses to lime and $\mathrm{P}$ applications on this site cannot be fully understood from the present results, a possible sequence of events is as follows:

(1) Because of poor legume growth, the primary factor limiting pasture growth is $\mathrm{N}$ deficiency. There is also an incipient $\mathrm{P}$ deficiency. Thus, the initially observed treatment effect is due to liming stimulating grass growth by increasing the pool of available $\mathrm{N}$. This pattern is observed in years one and two.

(2) By the third and fourth years, there is a significant legume component in the sward, a reaction to the low $\mathrm{N}$ status and to more favourable autumn reseeding conditions for the annual legume. Thus the $\mathrm{P}$ requirement of the pasture increases and hence response to $\mathrm{P}$ applications are observed. Consequently, more available $\mathrm{N}$ accumulates through symbiotic $\mathrm{N}$ fixation and recycling and hence any beneficial effect of liming on $\mathrm{N}$ mineralisation is masked and not observed.

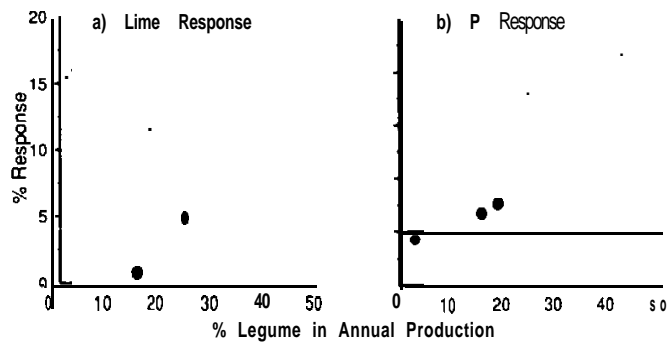

Figure 4 Relationships between the average annual pasture legume composition ( $\%$ on dry matter basis) and (a) annual total pasture dry matter response to lime (average of 5 and $10 \mathrm{t} / \mathrm{ha}$ ) and (b) annual total pasture dry matter response to phosphorus $(50 \mathrm{~kg} / \mathrm{ha} / \mathrm{yr})$. 
(3) By the fifth year, $\mathrm{N}$ in the system is sufficient to mask any beneficial effect of lime on $\mathrm{N}$ mineralisation. Also grass growth is encouraged at the expense of the legume and hence the $\mathrm{P}$ response diminishes. Thus the pasture begins the decline to the beginning of the next cycle.

\section{Conclusions}

(1) On this dryland soil pasture botanical composition was extremely variable between years.

(2) The size of the lime and $\mathrm{P}$ responses was related in part to the botanical composition of the pasture. (3) The major effect of liming was initially to enhance grass production, presumably by increasing the rate of net soil $\mathrm{N}$ mineralisation.

(4) There was no consistent evidence that $\mathrm{P}$ inputs could be substantially reduced by liming.

(5) The use of pasture composition as a factor to predict, and hence model lime and $\mathrm{P}$ responses should be seriously considered.

\section{REFERENCES}

Cullen, N.A.; Grigg, J.L. 1971. Establishment of pasture on yellow-brown loams near Te Anau. NZ journal of agricultural research 14: 1-9.

During, C. 1972. Fertiliser and soils in New Zealand farming. Bulletin NZ Department of Agriculture, 409. Wellington, Government Printer.
Edmeades, D.C.; Judd, M.; Sarathchandra, S.U. 1981. The effect of lime on nitrogen mineralisation as measured by grass growth. Plani and soil 60: 177-186.

Edmeades, D.C.; Pringle, R.M.; Shannon, P.W.; Mansell, G.P. 1984. Effects of lime on pasture production on soils in the North Island of New Zealand 4. Predicting lime responses. NZ journal of agricultural research 27: 371-382.

Edmeades, D.C.; Feyter, C.; O'Connor, M.B. 1984. Lime and phosphorus requirement for hill country yellowbrown earths. Proceedings of the NZ Grassland Association 45: 98-106.

Edmeades, D.C.; Rys, G.; Smart, C.E.; Wheeler, D.M. 1986. Effect of lime on soil nitrogen uptake by a ryegrass-white clover pasture. NZ journal of agricultural research 29: 49-53.

Edmeades, D.C.; Wheeler, D.M.; Pringle, R.M. 1989. Effects of liming on soil phosphorus availability and utilisation. In Symposium on phosphorus requirement for sustainable agriculture in Asia and Oceania (Eds S.J. Bantu and H. Tiespen) International Rice Research Institute, Manila 6-10 1989.

Mansell, G.P.; Pringle, R.M.; Edmeades, D.C.; Shannon, P.W. 1984. The effects of lime on pasture production on soils in the North Island, New Zealand. 3. Interaction of lime with phosphorus. NZ journal of agricultural research 27: 363-369.

Nyborg, M.; Hoyt, P.B. 1978. Effects of soil acidity and liming on mineralisation of soil nitrogen. Canadian journal of soil science 58: 33 1-338.

Saunders, W.M.H.; Sherrell, C.G.; Gravett, J.M. 1987. Calibration of Olsen bicarbonate phosphorus soil test for pasture on some New Zealand soils. NZ journal of agricultural research 30: 387-394. 